\title{
The 'Armed Thaw': Cultural War under Peaceful Coexistence A Comparative Study between the 1950s and Today
}

\author{
Raphaelle Auclert
}

\begin{abstract}
The article proposes a comparative study of the Soviet Thaw, initiated by Nikita Khrushchev after the 20th Congress of the Party, and the contemporary Russia with a special emphasis on the international relations between Russia and the United States. Attempts have been made to draw some parallels between the Khrushchev Thaw and the President Putin parade diplomacy. The paper provides a detailed analysis of the parade diplomacy and neo-Stalinist tendencies hovering over the country today as well as dwells upon the role of carnival within Russian propaganda shedding a new light on the Kremlin actual strategy.
\end{abstract}

Over the past seventy years the United States and the Soviet Union (afterward Russia) were two powers with the unchanged vital interests and constant diplomatic course. Obviously they have gone through numerous ups and downs in their relationship also called the periods of détente and tensions. The Thaw, beginning from the 20th Party in 1956, where the doctrine of peaceful coexistence was put forward by the Soviet leader Nikita Khrushchev, and lasted until the end of his rule in 1964, was a notorious phase of détente. From 1955 until 1960 the Soviet-American relations reached their peak. However, even this idyll was not free from hostility. Indeed, the paradox of the Thaw period lies in manifesting official friendly diplomacy both by the Soviet Union and the US in the "Spirit of Geneva" and simultaneously practicing the fiercest offensive on the cultural field since the wartime. By studying those five years of outstanding closeness between the "natural enemies," one can better understand their most intimate motives and expectations.

This paper falls into two parts: firstly, it expounds on the roots of the Thaw ideology shaped by Russia's traditional ambivalent relationship to the West, in fact an eerie mix of fear and attraction as shown by the Soviet diplomatic and cultural choices during the second half of the 1950s. Moreover, Soviet official prose elaborated this eerie narrative transforming the Thaw political language into literature and making it more accessible to the masses. The paper deals precisely with two case studies of Socialist Realist authors - fussy followers of the Party line - and makes an attempt to extract the ideological content from their works. Secondly, I assume that if history does not repeat itself it often rhymes. Basing on

1 Robert C. Grogin, Natural Enemies. The United States and the Soviet Union in the Cold War, 1917-1991 (Lanham : Lexington Books, 2001). 
this assumption, a parallel is drawn between two five years periods: 1955-1960 and 2009-2014. A closer look at the 2009-2014 years will reveal the fact President Obama's double mandate has indeed much in common with Dwight Eisenhower's presidency. Apart from similarities in the geopolitical game between the US and the former Soviet Union in the 1950s and half a century later, the both countries share a common ground of political sensibility. This is why it seems crucial to elaborate a more accurate conception of the Thaw consciousness not only to understand the Kremlin current strategy, but also to grasp some key features of the Russian-American modus vivendi in the long run.

\section{1- Waging the Cultural War: Ideological Patterns of the Thaw An 'Armed Thaw'}

It seems that the oxymoron "armed truce," used by the scholar Hugh Thomas in his book on the beginnings of the Cold War, ${ }^{2}$ is also relevant for the Thaw period. In 1953 there were several factors involved in the pacification of international relations. Firstly, the change of leaders of the two superpowers gave hope that a compromise could be found easier than between "Uncle Joe" and the "petty shopkeeper" (as Joseph Stalin and Harry Truman scornfully called each other in private). Secondly, both the American and the Soviet people were exhausted after the first round of the Cold $\mathrm{War}^{3}$ and the Peace Movement had millions of supporters around the world. Thirdly, politicians were limited by the costs of war. In order to avoid "an unbearable security burden leading to economic disaster," President Eisenhower put forward the New Look policy in 1953 based on deterrence through the concept of massive retaliation. In his New Course speech, given before the Supreme Soviet on 8 August 1953, Georgy Malenkov seemed to hold a similar idea. ${ }^{5}$

Undoubtedly, Stalin's death allowed the diplomatic Thaw. On 15 March Malenkov-considered at the time as the Kremlin heir-delivered a speech before the Supreme Soviet, where he argued that conflicts between Moscow and Washington should "be decided by peaceful means, on the basis of mutual understanding." Washington then seized the opportunity of a brief power vacuum to engage in the path of the détente. On 16 April 1953 - only three months after his inauguration day_President Eisenhower delivered the "Chance for Peace Speech" where he clearly expressed his will to reduce defense spending and warned against the dangers of starting the arms race; in December of the same year it was followed by the "Atoms for Peace Speech." In July 1955, Khrushchev and Eisenhower first met at the Geneva Summit, dedicated to disarmament and inter-

2 Hugh Thomas, Armed Truce. The Beginnings of the Cold War. 1945-1946 (London: Sceptre, 1988). The title is inspired by a quote by Dean Acheson to President Truman on September 25, 1945: if co-operation is impossible, "there will be no organized peace but an armed truce."

3 On Soviet mentalities in the mid 1950s, see Yuri Aksîutin, "Khrushchevskaĭa Ottepel” $i$ obshchestvennye nastroenia v SSSR v 1953-1964 gg. (Moscow: Rosspen, 2010), 179-188; Hugh Thomas talks about a "truce of exhaustion" in Armed Truce, 32.

4 Samuel P. Huntington, The Common Defense (New York: Columbia University Press, 1961), 66.

5 Aksîutin, "Khrushchevskaîa Ottepel," 67 and Vladislav Zubok, A Failed Empire: the Soviet Union in the Cold War from Stalin to Gorbachev (Chapell Hill: the University of North Carolina Press, 2007), 96. 
national security. The summit enhanced communication and trust between the two states, arousing the so-called "Spirit of Geneva." About half a year later, the 20th Congress of the Party made a decision that Soviet foreign policy should be based on the principle of peaceful coexistence, articulated for the first time by Georgy Chicherin in 1922 and reaffirmed in the Third Program of the Communist Party in 1961. In September 1959, Khrushchev flew to the US; subsequently his visit was favorably highlighted in the books Living in Peace and Friendship, ${ }^{6}$ and Face to face with America. ${ }^{7}$ Needless to say, the diplomatic progress during this trip was negligible on both sides (related to the temporary lifting of the Soviet ultimatum on Berlin), but the result was that it showed the perception of the American people by the Soviet delegation summarized in Khrushchev's address to Americans on television, ending with the words: "Good bye! Good luck! Friends!"

As a token of the diplomatic rapprochement in US-Soviet relations in the wake of the Spirit of Geneva, cultural exchanges were significantly fostered during the Thaw covering almost all aspects of cultural and social life such as the theater, music, books, newspapers, broadcasts like Music USA, museums and exhibitions. ${ }^{9}$ In January 1956 the Soviets proposed a twenty-year treaty of friendship putting much stress on broader artistic contacts; later they advanced the idea of new film cooperation. On 9 October 1956, an agreement was signed for a renewed circulation of magazines within the two countries, such as Amerika and USSR. In return, the United States Information Agency raised the budget on cultural and information programs to $\$ 325$ million. ${ }^{10}$ This open-door policy culminated in the cultural agreement signed on 27 January 1958 (also known as the Lacy-Zarubin agreement), which implied the exchange of films, scholars, sportsmen, artists, and writers.

But cultural exchanges were dominated not only by philanthropy. At the very outbreak of the Cold War, state policies from both sides had already laid the ground for an intense cultural struggle; and during the Thaw, in an unexpected although logical way, the more the threat of an armed war moved away, the harder

${ }^{6}$ Zhit'v mire i druzhbe, translated in english Khrushchev in America (Moscow: Gospolitizdat, 1959). It gathered speeches, accounts on press conferences, and meetings of the Soviet leader.

7 Alexey Adzhubey (ed.), Litsom k litsu s Amerikoŭ (Moscow: Politizdat, 1960).

8 William Taubman, Khrushchev: The Man and His Era (New York: Norton and Company, 200), 439.

9 Useful studies on the influence of American and British music on the Soviet Union include: Danielle Fosler-Lussier, Music in America's Cold War Diplomacy (Berkeley: University of California Press, 2015); David Caute, The Dancer Defects: the Struggle for Cultural Supremacy during the Cold War (Oxford University Press, 2003), 377-467; Yale Richmond, Cultural Exchange and the Cold War: Raising the Iron Curtain (University Park, PA: Penn State University Press, 2004), 205-209; Penny M. Von Eschen, Satchmo Blows Up the World: Jazz Ambassadors Play the Cold War (Cambridge, MA: Harvard University Press, 2004), 10, 13, 34, 225; Alexander Bratersky, "Back in the USSR: The Beatles Shaped a Generation in Soviet Russia," The Telegraph, January 25, 2008.

10 Theodore Streitbert, "Memorandum for the President, " Sept. 4, 1955, General Correspondence ad Memoranda Series, Box 3, John Foster Dulles Papers, DDEL; FRUS 1955-1957, IX: 556-558, quoted in Walter Hixson, Parting the Curtain: Propaganda, Culture, and the Cold War (New York: St Martin's Griffin, 1998), 104. 
the propaganda offensive became. As for the CIA, it had created the Council for Cultural Freedom (CCF) in June 1950 in West Berlin in order to aggregate intellectuals against Communism and to promote an artistic production founded on liberal democratic principles. ${ }^{11}$ The CCF had operative offices in 35 countries and produced many publications, musical works and international events. In October 1950 the project TROY defined "the intellectual framework for waging total Cold War" and proposed models of cooperation between universities and National State bureaucracy to get information into the Soviet Union. ${ }^{12}$ When Eisenhower came to power, he planned to make psychological warfare the chore of the Cold War strategy, "understanding that the struggle was going on between the East and the West for people's minds and people's adherence," as one subordinate recalled. ${ }^{13}$

In the Soviet Union, on the suggestion of writer Konstantin Simonov to Malenkov, the Office for Agitation and Propaganda launched a "Plan of measures for the strengthening of anti-American propaganda in the near future" in April and May 1949. It allowed systematic work with the mobilization of all the Soviet propaganda players such as in the media, cinema, literature and the theatre. Impressive polemical production blossomed in the following years and until Stalin's death. But literature remained in the Soviet cultural arsenal. At the end of the war, the Soviet Union already had twenty years of experience of propaganda literature. According to the definition coined during the First Congress of the Soviet writers held in 1934, "Socialist Realism is the basic method of Soviet literature and literary criticism. It demanded of the artist the truthful, historically concrete representation of reality in its revolutionary development." In the 1930s the Red Army viewed fiction as "one of the most powerful tools for the organization and education of the masses." 14 This doctrine was maintained later on. Official literature was the language of power used to address its people and the whole world. At the Second Congress in 1954 Alexey Surkov, poet and First Secretary of the Directorate of the Writers' Union, proclaimed that "Literature is the sharp-edged weapon of socialist-political action." 15

\section{Under the Spell of the Enemy (the Party Line on the Western Threat)}

To be sure, mutual perception during the Cold War was not just shaped from above; the American citizens met it with eagerness: there was an "outpouring of enthusiasm for the American appearances of Soviet musicians Emil Gilels, David Oistrakh, and Mstislav Rostropovich in winter 1955 and spring 1956;"'16

11 Frances S. Saunders, Who Paid the Piper? The CIA and the Cultural Cold War (London: Granta Books, 2000), Chap. 4.

${ }^{12}$ Hixson, Parting the Curtain, 36.

${ }^{13}$ Hixson, Parting the Curtain, 21.

14 "Boevoĭ otrîad na fronte literatury" (Combat Detachment on the Literary Front), Literaturnaya Gazeta, August 5, 1930 quoted in M.T Hooker, The Military Uses of Literature. Fiction and the Armed Forces in Soviet Literature (Westport: Greenwood Publishing Group, 1996), 2.

${ }^{15}$ A.A. Surkov, "O sostoîanii i zadachakh sovetskoj literatury" (On the State and Tasks of Soviet Literature), in Vtoror s" ezd sovetskikh pisatele (Moscow: Sovetskii pisatel', 1956), 31.

${ }^{16}$ Hixson, Parting the Curtain, 107. 
during those years, about 2,500 American musicians, intellectuals and politicians visited the USSR. ${ }^{17}$ Reciprocally, far from being seen as an enemy, America was very popular among the Soviet population: "Embassy personnel, tourists, and other Westerners in Moscow received daily evidence, based on their contacts with Soviet citizens, of the growing appeal of Western ideas and information in the USSR." ${ }^{18}$ One example of the appeal of the American way of life for the Thaw generation was the American National Exhibition set up in Moscow in the summer of 1959. Harold McClellan, one of its chief organizers, suspected that its actual attendance exceeded the official figure of 2.7 million: "They came in under the fence and over the fence. On one crowded day I checked what seemed to me as high as twenty percent pushing their way in with no tickets at all, simply because the guards and ticket takers at the gate were unable to restrain them." ${ }^{19}$ Very early in the Thaw and despite the Kremlin's official position, "embassy personnel monitored evidence in the Soviet press of increased sensitivity to the danger of ideological contamination." "20 Another example is the World Festival for Youth and Students, held in Moscow in the summer of 1957: "to reduce the contacts between foreigners and ordinary people, the regime successfully strove to occupy the foreign guests, so that they had no time left." 21

In spite of regaining tensions at the beginning of the 1960s (like the U2 incident $^{22}$ or the Cuban Missile Crisis ${ }^{23}$ ), they did not change much in the perception

${ }^{17}$ J.D. Parks, Culture, Conflict, and Coexistence: American-Soviet Cultural Relations, 1917-1958 (Jefferson, NC: McFarland and Company, 1983), 153-171.

18 Hixson, Parting the Curtain, 114.

${ }^{19}$ Hixson, Parting the Curtain: 201; see also Susan Reid, "Who Will Beat Whom? Soviet Popular Reception of the American National Exhibition in Moscow, 1959," Kritika: Explorations in Russian and Eurasian History, 9 (4) (2008), 855-904. Reid characterizes the Soviet reception of American way of life as more complex and contradictory than only appeal. Resorting to the comment books of the exhibition, it appears that, in spite of the fascination for American goods, the Soviet people expressed their pride for socialist values of equality, education, work: "they did not accept the acquisitive consumerist domesticity represented by the exhibition as the measure of modernity and freedom" and called for a "different model of consumer society."

${ }^{20}$ John C. Guthrie, "Soviet Sensibility to Possible Contamination Effects of EastWest Cultural Ties," January 8, 1957, Box 42, Dwight D. Eisenhower Diary Series, DDEL quoted in Hixson, Parting the Curtain, 114.

${ }^{21}$ Aksîutin, "Khrushchevskaîa Ottepel'," 302.

22 On 1 May 1960, the Soviet Air Defence Forces shot down a United States U-2 spy plane while it was performing photographic aerial reconnaissance deep into Soviet territory. The pilot Francis Gary Powers parachuted safely and was captured. It happened around two weeks before the opening of an east-west summit in Paris. At his arrival, Khrushchev said he would only take part to the negotiations after the US publicly apologized for the spy plane. The American side refused and the Soviet delegation left the summit ; consequently, Eisenhower's planned trip to Moscow in June was scrapped.

${ }^{23}$ The Cuban Missile Crisis was a 13-day (October 16-28, 1962) confrontation between the United States and the Soviet Union due to American ballistic missile deployment in Italy and Turkey with consequent Soviet ballistic missile deployment in Cuba. It was the highest point of tension during the Cold War, when the superpowers came closer than ever to nuclear war. 
of the American world. On the opposite, the Soviet and American people have developed solidarity by experiencing the same threat, urged both by the mutually assured destruction doctrine and by adventurous hotheaded leaders. Short in time, unexpected and paroxysmal, these crises left nothing more than a purely political, superficial impact on the overwhelming majority of the Soviet people, and the US continued to hold the Soviet imagination under their spell. Despite the official media's attempts to diminish the importance of the Western appeal to Soviet youth, ${ }^{24}$ these events did not alter its greed for American material goods, way of life neither dampened their enthusiasm for jazz music. As Pyotr Vail and Alexander Genis rightly put it, "the 1960s did not know America, but they believed in it $\langle\ldots>$ 1963 - [John] Kennedy's murder is perceived in Russia like a national tragedy $<\ldots>$ the travel notes by Ilf and Petrov Little Golden America are a cult book." ${ }^{25}$

The Soviet leader was not an exception here; he too was hypnotized by his American counterpart. Without changing the Stalinist rhetoric, saying to his lieutenants that they would not be able to stand against the imperialists, ${ }^{26} \mathrm{Khrushchev}$ developed an inferiority complex, a mixed feeling of fear and fascination towards Eisenhower and his people. ${ }^{27}$ However, after the Soviet leader's triumphal trip to the United States in 1959, he decided to befriend the Americans. ${ }^{28}$ Victor Sukhodrev, a Soviet interpreter, who used to accompany Khrushchev to summit meetings, recalls that "Kennedy was the most impressive of all. No doubt he was an outstanding person, intellectual, handsome and charismatic $<\ldots>$ After his murder, Khrushchev was genuinely disappointed and sent his closest mate among the Soviet executives-Anastas Mikoyan $<\ldots>$ Shortly before his death, [Kennedy] delivered his "Peace Speech" at the American University, where he pleaded for a turning point in the Soviet-American relations and for a kind of "reset." This endeavor was positively met by Khrushchev. ${ }^{29}$

${ }^{24}$ In his conclusions on monitoring the values Soviet youth conducted in 1961 by the newspaper Komsomolskaya Pravda, author Boris Grushin argues that "the second place of this negative feature (i.e. sycophancy of the youth toward the West) after drunkenness was very unexpected by the specialists; they related that to one of the massive misperceptions of public opinion $\langle\ldots\rangle$ that belief has proved to be deeply exaggerated $\langle\ldots>$ copying of the Western fashion is viewed as a thorn in the flesh, as a provocative, unacceptable, unfamiliar and thus dangerous thing" see Boris Grushin, Chetyre zhizni Rossii v zerkale oprosov obshchestvennogo mnenîa. Ocherki massovogo soznanîa rossiyan vremion Khrushcheva, Brezhneva, Gorbacheva i Eltsina v 4-h knigah. Zhizn'1-îa. Epoha Khrushcheva (The Four Lives of Russia in the Mirror of Public Opinion Polls. Essays on the Russian Collective Consciousness under Khrushchev, Brezhnev, Gorbachev and Eltsin in four volumes. Life Number 1: Khrushchev's Time) (Moscow: Progress-Traditsîia, 2001), 208-209, 216, 418.

${ }_{25}$ Pyotr Vail and Alexander Genis, 60-ie: Mir Sovetskogo Cheloveka (The 1960s: the World the Soviet Man) (Moscow: Corpus, 2013), 39.

${ }_{26}$ Fiodor Burlatskiü, Nikita Khrushchev (Moscow: Ripol Classic, 2003), 191.

27 Aksîutin, "Krushchevskaîa Otepel'," 328; Hixson, Parting the Curtain, 177.

${ }^{28}$ Leonid Mlechin, Khrushchev (Saint Petersburg: Amfora, 2015), 406.

${ }^{29}$ Data from Victor Sukhodrev's speaking at the radio channel Ekho Moskvy. Quoted in Vitaly Dymarskiı̌, Vremena Khrushcheva. Vliudiakh, faktakh i mifakh (In Khrushchev's Times. People, Facts and Myths) (Moscow: AST, 2011), 312-313. 
Depicted in the lexicon borrowed from virology, this ideological contamination was the core of the Soviet doctrine towards the US during the Thaw. The enemy was no longer a spy aimed to cause material or physical damage to the country (like the saboteurs in the 1930s or the Nazi invaders); this new enemy was feared for his subversive actions and possible impact on the imaginary world and moral consciousness of the Soviet people. Like the snake in the Garden of Eden, the threat coming from the US was no longer destructive but seductive. ${ }^{30}$ Two novels published during the Thaw present a particularly high ideological value in regard to their double function: not only did they reflect the mottos of power at a precise time, but reciprocally, their content has contributed in shaping the Soviet picture of the Western threat.

\section{Case studies of two Thaw heralds: Vsevolod Kochetov and Ivan Shevtsov}

The first author, Vsevolod Kochetov (1912-1973) was a Stalinist orthodox. After he spent World War II on the front line as a war correspondent, he began his literary career with military prose. With The Brothers Yershov (1958) and What Do You Want Then? (1969), he engaged in ideological debates in the wave of intense cultural antagonism with the West and of the technical revolution. In those two books, he displays the principles of socialist ethics and blames subversive action of the imperialist camp against the Soviet Union. Also, from 1954 he was a member of the Writers' Union executive board. Later in 1961, he was appointed as the editor-in-chief of the journal Oktîabr', the mouthpiece of the conservative wing, consisting of Marxist ideology_-basically National bolshevism ${ }^{31}-$, and the Socialist Realist canon. In 1959, it became the writers of the RSFSR' ${ }^{32}$ organ, which aimed to counterweight the authors of liberal sensibilities published in Novy Mir.

Except for Novy Mir and Oktîabr', the third voice in the literary polyphony of the Thaw was Molodaîa Gvardiîa. ${ }^{33}$ Inspired by the ideas of the Slavophiles, the editorial line was genuinely patriotic. Certainly not all nationalists were antiSemite; however, some of them had supported the anti-cosmopolitan campaign; among them, the sculptor Evgeny Vuchetich was one of the leaders of the socalled "Russian Party." 34 They were convinced of the importance to inform the

${ }^{30}$ One can find a concentration of such views in the book by Mikhail Lifshitz and Lidiîa Reinhardt, The Crisis of Ugliness (Moscow: Iskusstvo, 1968). It contains a paper written by Lifshitz in 1963 untitled "Why Am I Not a Modernist?" His answer can be resumed in a few words: "modernism is the greatest treason by the mandarins of culture $<\ldots>$ the petty adjustment by professors and men of letters to the reactionary politics of the imperialist states, $<\ldots>$ the Gospels of the new Barbarism, $<\ldots>$ voluntary obscurantism," 187-188.

${ }^{31}$ David Brandenberger, National Bolshevism: Stalinist Mass Culture and the Formation of Modern Russian National Identity, 1931-1956 (Cambridge, MA: Harvard University Press, 2002).

${ }^{32}$ Russian Soviet Federative Socialist Repuiblic

${ }^{33}$ On the patriotic movement, see Nikolaĭ Mitrokhin, Russkaîa Partîia: Dvizhenie Russkih Natsionalistov v SSSR, 1953-1985 gg. (The Russian Party: the Russian Nationalists' Movement) (Moscow: Novoie Literaturnoie Obozrenie, 2003), 160-169 on the nationalist literary circles.

${ }^{34}$ Mitrokhin, The Russian Party. 
Party about the Jewish influence on Soviet artistic life. In 1949, Vuchetich befriended the writer Ivan Shevtsov (1920-2013) - the second author of the case study - after the latter had published an article, "Against the anti-patriotic critics in the battle painting. ${ }^{"}{ }^{35}$ Afterwards, Shevtsov became one of the representatives of the Russian Party. He also belonged to the generation of war- he had fought during World War II as a border guard. Then he worked as a special correspondent and as a deputy editor-in-chief of several newspapers. But his journalistic career was put to an end following the scandal around the publishing of Plant Louse (1964), his novel targeting the Jewish liberal intelligentsia and its deleterious influence on Soviet society.

In his work, Shevtsov described the ideological struggle between a group of Russian "realists" and art critics in favour of abstract art. Most of them were Jewish and gathered under the auspices of Lev Barselonsky, a clear allusion to Ilya Ehrenburg. The novel, a "rabidly anti-intellectual, Stalinist novel," ${ }^{36}$ was written in 1950 in the wake of the cosmopolitan campaign. But it was published only after Khrushchev's attack on avant-garde artists at the Manezh Exhibition. Many years later, the author recalled Vuchetich's phone call: - "I will tell you the details in person, he said in excitement. I am now at home with [Aleksandr] Gerasimov, [Aleksandr] Laktionov, and other comrades. We just arrived from the Manezh. Join us immediately. You have precisely a novel on painters. It's just the right time now. ${ }^{\prime 37}$ And one hundred thousand copies of Plant Louse were published. The novel urged a salvo of outraged criticism, ${ }^{38}$ and the new host of the Kremlin eventually decided to get rid of an embarrassing courtier of his predecessor.

Although What Do You Want Then? dates back from 1969, it is associated with the Thaw, since it is a concentration of its author's views, a typical character of that time. The intrigue of the novel is simple: the capitalists decided to undermine the Soviet Union from within. To achieve this goal, they resorted to the services of various people who had personal reasons to settle accounts with the communist system, for example, the CIA agent Portsia Brown, former SS Uwe Klauberg, who wanted to take revenge after the lost war. His colleague Peter Saburov, the son of a white emigrant, promised to return to former Russia, from where he fled with his parents while still a small child. Implementing a UNESCO treaty in the field of cultural relations between the US and the Soviet Union, this unlikely team hid a Machiavellian plan: to conduct a sabotage action under the pretext of the publishing order by the London based publishing house "New World," which wanted to show the world photographs of the best Russian icons. So, Kochetov displayed a team of Apostles of Evil engaging in the 'cold crusade.'

${ }^{35}$ Ivan Shevtsov, Nikolaĭ Zhukov, Khristofor Ushenin, "Protiv kritikov-antipatriotov v batal'noŭ zhivopisi," Krasnaîa Zvezda, April 1949.

${ }^{36}$ Yitzhak Brudny, Reinventing Russia: Russian Nationalism and the Soviet State 1953-1991 (Cambridge, MA: Harvard University Press, 1998), 64.

${ }^{37}$ Ivan Shevtsov, Plant Louse (Moscow: Golos, 2000), 3.

38 Zinoviı̌ Papernyı̆, "Agressivnoe Nevezhestvo" (Aggressive ignorance), Yunost', 12 (1974); Nikolaĭ Nikolaev, "Salopnitsa pishet roman" (Scandalmonger writes a novel), Ogoniek, 48 (1964). 
They planned not a violent aggression, but a soft conquest: "they will go to Russia not with axes, not with gallows, but with banners of ideas of good, friendship of peoples. ${ }^{{ }^{39}}$ In a certain sense, Kochetov is the Soviet John Le Carré, who almost at the same time (six years earlier) published the novel The Spy that Came from the Cold; abroad, the novel was correctly called "James Bond in reverse." ${ }^{\text {" }}$ As for Piotr Strokov, a literary critic and longtime collaborator of Kochetov at the editorial board of Oktîabr', he interestingly enough noticed the resemblance between Kochetov's novel and Gogol's Dead Souls: "Chichikov visits the landlords in order to buy from them the dead souls of their peasants. Here Portsia Brown and co travel in order to deprave living souls." ${ }^{41}$ Moreover, Kochetov did not just warn against foreign agents. He criticized the Soviet liberal artists as well; incidentally, following the publishing of the book, twenty members of the intelligentsia signed a letter protesting against the "obscurantist novel." This is how they are described: "Miss Brown knew some Soviet writers, artists, directors who had signed an Appeal calling the intelligentsia to change the system. She spoke about them with great sympathy." ${ }^{42}$ Among them were supporters of Abstract Expressionism, an art tendency the author is manifestly not fond of; when two heroes are invited to the office of the vice-director of the publishing house, they notice on the walls "abstract bright spots and gloomy chaos in frames and without frames." ${ }^{43}$

Hence, both novels illustrate the three main patterns of the Thaw. First, the neo-Stalinist line appears through constant reference to patriotism and to national pride linked with the victory during World War II. From that perspective, the Soviet Union played the role of the liberator of the world from absolute evil, i.e. the Nazis (second pattern). One can find an echo of this messianic discourse in Vladimir Putin's will to "be remembered in history as the fighter against the jihadists." ${ }^{" 44}$ Finally, although the theme of anti-Semitism is totally irrelevant concerning the current president, he shares an instinctive and deep distrust with the two authors towards the liberal intelligentsia, also called by Kochetov the "educated bourgeois-individualist." ${ }^{45}$ When asked about the loyalty of Russian elites and their role in the national history, Putin began by recalling "the existence in every society of bacilli destroying the state organism, which are activated when immunity falls off." Then he quoted the poet Alexander Pushkin, who said that "there are many people who stand in opposition not against the government, but against Russia. Unfortunately, such a tradition exists in our intelligentsia," concluded the president, ${ }^{46}$ truly speaking as the Thaw ruler.

${ }^{39}$ Vsevolod Kochetov, Chego Zhe Ty Khochesh? (What Do You Want Then?) (Letchworth-Herts: Prideaux Press, 1970), 14.

${ }^{40}$ Mark Slonim, The New York Times, December 14, 1969, 28.

${ }^{41}$ Pyotr Strokov, Vsevolod Kochetov. Stranitsy zhizni, stranitsz tvorchestva (Vsevolod Kochetov. Pages of his Life and Work) (Moscow: Sovremennik, 1985), 341.

${ }^{42}$ Kochetov, Chego Zhe Ty Khochesh?, 80.

${ }^{43}$ Kochetov, Chego Zhe Ty Khochesh?, 68.

${ }^{44}$ Staffan de Mistura, United Nations Envoy to Syria, in an interview to Swiss TV channel RTS on 19 October 2016.

${ }^{45}$ Strokov, Vsevolod Kochetov, 163.

${ }^{46}$ Interview of Vladimir Putin to Pervy Kanal and Associated Press on 3 September 2013, right before the G20 Saint Petersburg Summit. 


\section{2-Thaw II}

The reset has failed, once again

Indeed, it is tempting to compare the period of peaceful coexistence between 1955-1960 (Thaw I) with the short "reset" established by President Obama in 2009 until 2014 (Thaw II). In both cases, after the Grand Alliance (Yalta in 1945 and 9/11 in 2001) followed by a series of skirmishes (the rivalry in Western Europe after the war, color revolutions and the war in Georgia in the 2000s), the new host of the White House was holding out a hand to Russia. In 2009, the physical handing out of a reset button by Hillary Clinton to Sergey Lavrov in Geneva is not without reminding us of the 1955 "Spirit of Geneva;" later in July, President Obama himself flew to Moscow to meet President Putin. In both double mandates, the international political agenda was focused on four key issues: the nuclear question ("Atoms for Peace" and "Open Skies" in 1955 and the New START Treaty in 2010), Asia (Korea in particular), the Middle East (Operation AJAX in Iran and the Suez Crisis in the 1950s and the Syrian war today), and the fate of Europe. However, the front line moved from Berlin, with the Soviet ultimatum in 1958 , to the conflict in the Donbass. Also, in spite of the official line of appeasement, Thaws I and II were times of intense cultural infiltration and witch hunts. ${ }^{47}$ All was happening as if the same diplomatic storyline were staged anew, and the outcome did not have a happy ending.

Eventually, those policies systematically failed and turned into huge crises, both paroxysmal and unexpected: the U2 incident caused the irrevocable breakup between Khrushchev and Eisenhower. The overthrow of Viktor Yanukovych after the Maidan protests in winter 2014, followed by the crash of the plane MH17 over the combat zone in Ukraine, have led to an open confrontation between the two countries and never-ending waves of economic sanctions. Finally, those sequences are similar even in their developments: after Kennedy's short mandate, his successor was Lyndon Johnson, whose renowned "Johnson treatment" is not far from the dominating handshake of Donald Trump, or "Trump Pumps." Beyond their psychological features, both presidents ran a policy oriented towards re-centering on domestic problems and international disengagement (such as the US withdrawal from the Paris climate accord, UNESCO and the Iran nuclear deal in 2017 and 2018). Against that background narrative, it seems as though the same political options are repeating themselves in contemporary Russia, but they are taking new shapes today.

${ }^{47}$ The Soviet 1950s have counted noteworthy political processes (the most famous one is the Pasternak trial in 1958). On 13 July 2012, the Duma adopted the foreign agent law (Federal law N 121-Ф3) compelling non-governmental organizations to designate themselves "foreign agents" if they engage in politics and are funded by foreign states. Also, an interesting fact is the resurfacing in 2014 of a ghost from the Thaw. General Philipp Bobkov, who was appointed in 1956 as a head of KGB Fourth Directorate (ideological counter espionage), published Struggling with “Agents of Influence?" How Putin Can Rebuild Russia (Moscow: Algoritm). In the US, the second Red Scare lasted until 1956. The US Justice Department has recently demanded state-funded RT channel Russia Today to register under the FARA (Foreign Agents Registration Act), what it eventually did on 13 November 2017. 


\section{Old patterns and new battlegrounds}

For the Soviets, the main pattern of the Thaw is the relationship towards the US, perceived as a threat of seduction arousing a mix of fascination and fear, of appeal and distrust (see above). In his time, Ambassador Llewellyn Thompson detected an inferiority complex. ${ }^{48}$ The latter might be explained by compensation through Khrushchev's favorite idioms such as "We'll catch up and overtake America," "We'll show you Kuzka's mother"49 and today, the regular call of Russia to dialogue based on equal treatment with the US..$^{50}$ The second feature is the neo-Stalinist discourse and the paradigm of victory, which finds an echo in contemporary public opinion ${ }^{51}$ and in the celebrations of Victory Day. Finally, the last pattern is the spiritual mission of the Soviet Union: after the 20th Congress, the commitment to Third World countries became important (although this idea was inherited from Vladimir Lenin). Khrushchev "regarded aid as the main instrument for carrying out Soviet policy and strategy," 52 to make a "peaceful transition" by post-colonial states towards socialism. Nowadays, instead of the communist path, the Kremlin promotes Russia as the keeper of Christianity in Europe and of the Christians in the Middle East with the open support of the Russian Orthodox Church ${ }^{53}$ besides, it was not a coincidence that from March to June 2017 Patriarch's Palace (one of the Moscow Kremlin Museums) was hosting an exhibition dedicated to Saint Louis, the pious French king who introduced reforms to renew the kingdom's morality (for instance, he decided to punish the blasphemy and interest-blaming loans) and took part in the Seventh and Eight crusades. However, one may wonder if this mystical rhetoric corresponds to a genuine diplomatic aim per se; is it not rather a way to take the opposite view to the US and to reinforce the prestige of Russia in the international stage and its historical destiny?

${ }^{48}$ Hixson, Parting the Curtain, 177. Llewellyn Thompson (1904-1972) served as American Ambassador in the Soviet Union from 1957 to 1962.

${ }^{49}$ Meaning "we'll teach you a lesson." Khrushchev used it many times during his meetings with foreign leaders, in particular with Richard Nixon during the American exhibition in Moscow.

${ }^{50}$ See "we must finally begin to build relations on the basis of equality, mutual respect, and of mutual consideration of interests." Extract from Vladimir Putin's speech at the Meeting of ambassadors and permanent representatives of Russia on 1 July 2014; see also "Putin tells Obama he wants dialogue based on equality and respect," Reuters, July 4, 2015.

${ }^{51}$ A poll conducted by the Levada Center in June 2017 showed that Russians consider Stalin, Putin and Pushkin as the most outstanding individuals in the history of mankind (they got respectively $38 \%, 34 \%$ and $34 \%$ ).

${ }^{52} \mathrm{Gu}$ Guan-Fu, "Soviet Aid to the Third World an Analysis of Its Strategy," Soviet Studies, 35-1 (1983), 71-89, 71; see also, Ermarth Fritz, "The Soviet Union in the Third World: Purpose in Search of Power," The ANNALS, April 1969. The "peaceful transition" approach to foreign aid was proposed by Khrushchev at the Twentieth Congress.

53 "Having started a military operation in Syria, Vladimir Putin began to be considered a defender of Christians in the Middle East," quoted from "Il Giornale: ROC defends the "political war" of Putin in Syria," Russia Today, January 17, 2016 (russian.rt.com/ inotv/2016-01-17/Giornale-RPC-vstala-na-zashhitu, consulted on 10 September 2018) 
In any case, after the Soviet Union lost the ideological battle in 1991, the propaganda war moved to new battlegrounds, for example, to economics. Tellingly, the most widespread weapons in economic warfare are sanctions. So how can these sanctions be considered as the tools of propaganda? To understand this shift, one has to keep in mind that propaganda is all about assumptions. In fact, the very word "sanction" implies that Russia is punished for its misconduct, it automatically sets a specific ratio of power where the US are the severe teacher and Russia is the clumsy pupil. After 2014, the new confrontation was accompanied by several waves of sanctions. Apart from measures striking a wide range of productive sectors or, on the contrary, some specific items of sensitive technologies, V.I.P. sanctions (also called smart sanctions) were introduced during the last years. They consist of raising the costs for the elites, following the example of the EU ban towards North Korea (in retaliation to its nuclear test in 2006, the EU banned exports of luxury goods). In the case of Russia, visa bans and asset freezes had already been implemented in 2012 in the frame of the Magnitsky Act. In 2014, it concerned individuals whose actions were found to "undermine democratic processes and institutions in Ukraine," namely tens of Russian officials. ${ }^{54}$ In addition, on 22 August 2017 the US Treasury ordered "U.S. title insurance companies to identify the natural persons behind shell companies used to pay for high-end residential real estate in seven metropolitan areas, including Miami-Dade, Broward, Palm Beach, New York and Los Angeles, the favorite Russian destinations. ${ }^{95}$

Another aspect of the confrontation is the stadium war, which was significant during the 2014 Winter Olympics in Sochi. If Olympics have always been the show case of the host nation-like the 1980 Summer Olympics in Moscow-the Sochi games were certainly a gigantic project to the glory of Putin's Russia. The climax of the most expensive games in history was the opening ceremony, a live epic recounting Russian history with no less than 3,000 artists on the stage. Moreover, the boycott or support of the games were a kind of vote on strategic and ideological choices made by Russia for the other nations, concerning such topics like the conflict in Ossetia in 2008, the recent law on gay propaganda for minors passed in 2013, or the Maidan protests. Afterwards, the prestige of the games was strongly tarnished by the McLaren report, published in 2016 and detailing a statesponsored doping program operated by Russia; the latter caused a ban for Russian athletes from competing at the Rio 2016 Olympics and Paralympics. A reflection of the 1959 American Exhibition, ${ }^{56}$ this diplomatic sequence reminds one of the

\footnotetext{
54 "Executive Order. Blocking Property of Certain Persons Contributing to the Situation in Ukraine." The White House, March 6, 2014.

55 "Putin's greatest weakness may be located on US shores," The Hill, October 17, 2017 (thehill.com/opinion/finance/355798-putins-greatest-weakness-may-be-on-usshores, consulted on 10 October 2018).

56 The Soviet Communist Party decided "to mount a massive propaganda campaign to counteract the potential appeal of the exhibition (...), depicting it as a blatant propaganda display that bore little relations to the realities of everyday life of the average U.S. citizen," see Hixson, Parting the Curtauin, 185-186.
} 
quarrels between the best player and the fair player. Just like the sanctions, it consists in a struggle for moral superiority in order to legitimize one's leadership.

The information war is the last field of confrontation. This art of war swallows all the other ones, opening new fronts and justifying the battles' proceedings (like the announcement of new sanctions) by ethical and political categories. A merciless information war was raging during the most intense fighting in Ukraine ${ }^{57}$ and with regard to Russian interference in the last American elections. It consists of disinformation campaigns and of a tougher monitoring of social networks and news websites in order to control the national web space and to establish a "digital sovereignty." 58 Obviously today, with the democratization of smartphones and Internet, social networks, such as Facebook, Twitter or Instagram, replaced the literary journals and jazz songs of the 1950s. And, for sure, Moscow is eager to have its say in the choir of tweets.

\section{The Kremlin's parade diplomacy}

Unlike the successful integration of the Concert of Europe at the Congress of Vienna, the Russian attempt to join the 'Atlantic symphony' bitterly failed two centuries later. After the Georgian War in 2008, seen by the Kremlin as a challenge of its power in the "Near Abroad," the government definitely changed the vector towards an enduring model separated from the rest of Europe. Besides, this shift took over the slavophile legacy, a nineteenth century intellectual current assuming the unique destiny of Russia and elaborated in Nikolay Danilevsky's Russia and Europe (1871). Russia is believed to belong to a specific historical=cultural type designated as a Slavic world distinctive from the European one, and also called the "German-Roman." According to the author, Russia's otherness is related to its critical mass, to the hostility of the European powers, and to a peculiar state of mind of the Russian people articulated on its organic relation to its leader.

In 2006 already, Deputy Prime Minister Vladislav Surkov's concept of “sovereign democracy" hinted at a strong state policy, and the President's Munich Speech (2007) marked a break with the unipolar system under American hegemony. But the geopolitical turn was still lacking an ideological content. In national history, the last state doctrine was the Stalinist one, also sometimes called "national-bolshevism" in the sense of state building on revolutionary principles. ${ }^{59}$ However, if the Stalinist model was designed for the "work in progress" of the Soviet state, one has to keep in mind that only the Thaw has given the ideological frame of the (almost) achieved Stalinist utopia. The Thaw, although discarding Stalinism on moral grounds, paradoxically gave it a historical legitimacy. The latter lies in the fact that the country under Stalin won the war and made its breakthrough towards communism - the rest was quick to achieve. Communism

${ }^{57}$ Jill Dougherty, "Everyone Lies: the Ukraine Conflict and Russia's Media Transformation," Discussion Papers $n^{\circ} 88$, Shorenstein Center on Media, Politics and Public Policy, Harvard Kennedy School, July 2014.

${ }_{58}$ Tsifrovol suverenitet, the term was pronounced by MP Sergey Zhelezniak, in Ekonomika i Zhizn', June 19, 2013.

${ }^{59}$ Brandenberger, National Bolshevism. 
was fast approaching and Khrushchev's model was projected in the near-future. Hence, at the dawn of the twenty-first century, by a conceptual gravity pulling the world politics towards the past, Russian ideology happened to be the one of the Thaw. ${ }^{60}$ Moreover, the Thaw is the biographical background of the majority of the contemporary leaders (Putin himself was born in 1952), so it can seem logical that the latter reproduced the worldview by which they were informed.

So, what is that ideology like? The backbone of the Thaw period is the victory of World War II and subsequent patriotic pride. Another key aspect of this paper is that the Thaw belongs to the anthropological realm of the carnival, which draws new Space Time coordinates. More precisely, the carnival brings about a narrowing of space around the society performing it; the construction of the Berlin wall in 1961 epitomized this tendency. Consequently, experiencing the same thing at the same time, the social body gets more and more homogeneous. In addition, another typical characteristic of the carnival is the reversal of values; in the Rabelaisian tradition, the master becomes the servant, men dress like women, old ladies give birth and so on. ${ }^{61}$ Such a situation occurred after the ideological turnarounds in 1956 and in 1991: one morning, the people were told that all the previous values were false (the cult of Stalin, or the holiness of Bolshevik revolution), and everything that had been condemned therefore became praised. By the way, to this extent any expression with "post-" like "post-Soviet," implies such a symbolic reversal. An exception to the common order, the carnival allows the neighboring of the opposite, a short sequence of truce between sworn enemies; called peaceful coexistence in the 1950s or friendship in the 2000s. ${ }^{62}$

As master of ceremonies, the king occupies a special place in this political ritual. But recently, the Thaw style was subjected to adjustments: Khrushchev's peasant exuberance with his famous cheek and mimicry gave way to the secret services martial restraint; the white clown replaced the red clown. Staging sports

${ }^{60}$ Except from ideology, Putin's policy resumes the Thaw policy on the three crucial issues: space, mass housing development and mass events (World Festival of Youth and Students in 1957 and the 2018 Football World Cup); see: "Putin: RF dolzhna sdelat' mnogo shagov, shtoby vernut' pervenstvo v kosmicheskoy otrasli," in TASS, https://tass.ru/kosmos/5271251, 7 June, 2018; and "In Presidential Address to the Federal Assembly, Putin sets the target to build 120 millions of square meters of housing per year" in the article "Putin demanded anew to make housing affordable," in Vedomosti, https://www.vedomosti.ru/ realty/articles/2018/03/01/752505-putin-zhile, $1^{\text {st }}$ March, 2018. In addition, as a sign of the Zeitgeist, in 2017 the Tret'îakov Gallery dedicated an exhibition to the Thaw.

${ }^{61}$ Mikhail Bakhtin, Tvortchestvo François Rabelais i narodnaîa kul'tura srednevekov'îa i Renesansa (The Art of François Rabelais and the Popular Culture in the Middle Ages and the Renaissance) (Moscow: Khudozhestvennaîa Literatura, 1965). Inspired by Bakhtin, David K. Danow recently proposed a study of the carnival where the latter is presented as an archetypal pattern of the human psyche, filling a fundamental need to dissolve boarders and allowing the merge of opposite forces (official and unofficial culture, life and death among others), cf. The Spirit of Carnival: Magical Realism and the Grotesque (Lexington: University of Kentucky Press, 2004).

62 "Cordial Rivals: How Bush and Putin Became Friends," New York Times, June 18, 2001. 
body language, the Russian leader enjoys showing himself in his swimming pool and gym at his Novo-Ogarevo personal residence. Also, the president often recalls his feats as a judoka and appreciates the company of athletes among the people close to him. ${ }^{63}$ Sometimes the mask of the former KGB agent falls and he too demonstrates the skills of the showman. ${ }^{64}$

In the Venetian tradition, the anonymity of the mask was giving social immunity to the citizens. By allowing escape from the strains of public morality without transgressing respectability, the mask was building a "private space in the public space." ${ }^{65}$ Hence, the wearer of the mask was located in an "inviolable space." ${ }^{66}$ However, anonymity here must not be confused with permissiveness; on the contrary, the mask has introduced moral codes into social life. First, in order to safeguard this inviolability, insult was prohibited; second, it ensured the republican equality by limiting ostentatious wealth; third, since aristocracy and foreign public figures had to wear a mask, it had limited contacts with the foreigners and the transmission of secrets that could be damaging for the Republic. Analogously, Khrushchev who had condemned the terror and thus, had given to the Soviet people political freedom, tried to codify public life with a set of moral values. As for the role of the social mask, it was devoted to literature, sparking off an ambivalent situation; on the one hand, the debates around books (criticism in the newspapers, readers' letters, or just informal exchanges between the readers of official prose) created a free space of thought; on the other hand, political and literary institutions broadcasted a rigid official discourse on these books and a state discipline that influenced the readers' opinions and restrained their freedom. So in the Thaw carnival, the 'Bauta of literature' was leaving the mouth of the Soviet people uncovered, allowing the expression of a made-up, but new subjectivity.

Another crucial feature of the carnival is time. With Khrushchev, the Soviet official discourse made the shift from a performative model (Stalinist state building) to the reflexive perception of time. Like the burning of a mannequin at the climax of pagan celebrations, Soviet society under the Thaw was all turned towards the advent of the communist prophecy: "We will bury you!," Khrushchev warned Western ambassadors in 1956; later he claimed that "the current generation of Soviet people will live under communism." The difference lies in the fact

${ }^{63}$ See the official site of the Kremlin where the President is shown attending sambo and judo tournaments, or fishing during his holidays (putin.kremlin.ru, consulted on 10 October 2018). Moreover, Vladimir Putin has granted foreign sportsmen Russian nationality: boxer Roy Jones in 2015, Australian track cyclist Shane Perkins in 2017.

${ }^{64}$ See "Vladimir Putin sings and plays piano with celebrity friends" (www.telegraph. co.uk/news/newsvideo/8196192/Vladimir-Putin-sings-and-plays-piano-with-celebrityfriends.html, December 11, 2010, consulted on 10 October 2018), and "Putin jam: Russian president surprises audience, sings Soviet cosmonauts' song” (www.rt.com/viral/375040putin-sings-to-guitar/ January 25, 2017, consulted on 10 October 2017). Also, at the meeting of the club Valdai in October 2017, Putin commented on his participation in the upcoming elections by saying a joke on the impoverished oligarchs.

${ }^{65}$ Gilles Bertrand, Histoire du Carnaval de Venise (Paris: Pygmalion, 2013), 142, 124-151.

${ }^{66}$ Bertrand, Histoire du Carnaval de Venise, 125. 
that Putin's reflexive position is not turned towards the future but towards the past; if the Thaw literature was a promise fair, today the Kremlin's rhetoric is a memories fair.

A good example is the celebration of the seventieth birthday of 9 May Victory day. One of the main events there was the immortal regiment: a huge parade of citizens carrying the portraits of their relatives who fought during the war throughout the main cities of the country. In Moscow, the cortege led by the president counted no less than five hundred thousand people who walked over Red Square to the Moskvoretzkaya embankment. From that perspective, the May 9 parade can be seen as a typical carnival performance, where the portraits were used as masks, creating precisely a private space in the public space. In the ocean of the innumerable crowd, the very photographs of the beloved siblings were seals of anonymity. The social body, with his thousands of faces, was again unified behind its leader, saying the same prayer. In Putin's Russia, the road to paradise goes back to the glorious past.

In the light of the carnival paradigm, it appears that the Kremlin's foreign policy relates less to a crusade against any "evil empire" than to what can be called 'parade diplomacy.' Of course, foreign relations always include elements of drama, gesticulation and diversion. But the specificity of Moscow's diplomacy —and it is particularly relevant concerning its cultural aspect-can be resumed in three words related to the practice of parade: reduction (of the political scope), reaction (instead of action), and impression (that the Kremlin wants to produce on its foreign partners).

Actually the Russian state conducts its policy within a narrow ideological frame where public space must be morally and politically homogeneous, similar to the carnival space. The official rhetoric consists of variations on the themes of the glorious imperial/ Soviet past, orthodox faith, peace and education, but at the same time it includes an aesthetic of strength (physical as well as military). Like during the Thaw, the fear of any subversion by "contaminated" ideas and values is still vivid; $;{ }^{67}$ the sovereign domains of national history and knowledge are highly sensitive. Here one can find the reason for the revival in 2012 of the witch hunt directed against the NGOs and other presumed foreign agents, among them Society Memorial (dedicated to the victims of the Soviet power) and Dynasty Foundation (for scientific research). Analogously, in the case of any ideological dissonance in an art work, authorities are tempted to decontaminate the public space resorting to censorship.

Autumn 2017 offered two dramatic cases of concurrent narratives on national myths. The first one, Matilda (dir. Alexey Uchitel), is a movie dealing with the romance between the young heir of the throne Nicholas II and a prima ballerina. On the one hundredth year anniversary of the Revolution, the film spurred outcry among the Orthodox Christians who deemed it blasphemous with regard to

${ }^{67}$ During the Presidential Council for Culture and Art on 30 May 2007, Vladimir Putin stressed on the importance "to protect the Russian cultural singularity and to reinforce the national cultural and moral values"; he mentioned the necessity to raise a "cultural immunity" (kul'turny immunitet) among the young generation. 
the memory of the holy Tsar. Natalia Poklonskaya, a Member of Parliament and a member of the United Russia party, said that the film "insults the feelings of religious believers" and called for it to be banned. Although the launching of the film was originally scheduled in March 2017, protests began as early as November 2016. Furthermore, in February, the Radical Orthodox movement Christian State-Holy Rus' warned that "cinemas will burn" if Matilda was released. During the summer, another Orthodox activist drove a van containing gas canisters into a cinema in Yekaterinburg, the central Russian city where the royal family was murdered. After the authorities condemned the violence and postponed the screening for security reasons, the film was finally issued a 16+ certificate in August. So, acting as arbitrator between the pressure of its political ally (the Orthodox Church) and the authors of cultural production who challenged the official narrative, power uses the threat of censorship to alter the reception of the art work and to build a consensus on the national past. Besides, the resort to the conservative notes of the political keyboard has much in common with Khrushchev's strategy. If the dominant narrative happened to be challenged by liberal voices, the latter used to let go of its lead the neo-Stalinist Cerberus, see Kochetov's journal Oktîabr'. Such was the case in the debates on the war literature; members of Oktîabr"68 were supporting an epic view of the war held for the "historical truth" (pravda istorii) against the new wave of the military prose evoking the soldiers' sufferings, mainly published in the liberal-oriented journal Novy Mir. ${ }^{69}$

The second example of the Kremlin's cultural policy deals precisely with the myth of war. The film The Death of Stalin (dir. Armando Iannucci) relates, in a tone of comedy, the last days of the Soviet leader and the struggle for power following his death. Stalin himself and the Marshal Georgy Zhukov, the two official architects of the victory, are shown in a grotesque light. At one moment Marshal Zhukov kisses Khrushchev, an episode that inevitably carnavalizes the war hero, in other words explodes the myth onto him. The advisor from the Ministry of Culture immediately denounced a "planned provocation" that may have been "part of a Western plot to destabilize Russia." After several twists and turns, the release of the film was eventually forbidden. ${ }^{70}$ Here, the political maneuvering matters as much as the final decision. The ban and the debates it has spurred are enough to shape the public reception of the movie. One could say that by taking into account today's resources of downloading from the Internet, this censorship is rather informative than effective.

${ }^{68}$ On the role of the journal Oktîabr' in the ideological debates of the 1960s, and particularly on the "lieutenant prose," see Evgeny Dobrenko, "Uroki Oktiabrîa" (The Lessons of Oktîabr'), Voprosy Literatury, 2 (1995), 27-55.

${ }^{69}$ The so called "lieutenant prose" was opposed to the "marshal prose." The former included protagonists who were often the junior officers; it was performed by authors like Yuri Bondarev, Vasil' Bykov, Konstantin Vorobiov, Viatcheslav Kondratyev, Victor Kurochkin and Grigoriı̌ Baklanov.

70 "Russia considers ban on Armando Ianucci's film The Death of Stalin," The Guardian, September 20, 2017; "Russian Death of Stalin Distributor plans January Release," The Hollywood Reporter, November 16, 2017; "Russian Culture Ministry yanks distribution certificate for The Death of Stalin," TASS, January 23, 2018. 
Proceeding on from that, it appears that the Kremlin never acts but always reacts in the given paradigm. If it is it an artwork, it is censored (or threatened to be so); if it is economic sanctions, then counter-sanctions are implemented; in the case of allegations of Russian interference in European and American elections, so those are denied by the president. And yet, the cultural artillery offers many weapons in order to win hearts and minds and expand one's influence: books, movies displaying alternative narratives, testimonies of the adversary's former supporters... ${ }^{71}$ But such is not the Kremlin's goal. Conducting parade diplomacy, Russian power wants to show itself on the international stage, performing a domestic ritual at the same time. Diplomacy is thereby turned into an exhibition room, a Red Square on the world scale meant to display the jewels of the Russian civilization (the imperial palaces, literary classics) ${ }^{72}$ or arms shows, ${ }^{73}$ both are legacies from history. Firmly oriented towards the past, Moscow's policy raises the masks of the war heroes or of the Olympic mascots to prompt an identification process and to build a national consensus. Its parade dimension, limited to goals of pomp or intimidation, also explains its inertia.

\section{Conclusions}

So, the present study underlined common ideological patterns, originally articulated in the official prose, between the 1950s and Putin's presidency. It also gave an insight into the new battlegrounds of Thaw II between Russia and the US. Those patterns serve until now as a compass for the Kremlin's geopolitical strategy. They consist in the staging of a political carnival, the revival of neo-Stalinism, the fear of moral contamination by foreign values - in particular through the discourse of the liberal intelligentsia, and at the same time the proclamation of a Russian messianism. Moreover, defining its relations toward the US and Europe, Russia defines itself and draws its future. But the combination of the carnival dimension (by its very nature, an energy-consuming and temporary performance) with a conservative rhetoric, and the ageing of the ruling elites (most of them began their political career in the 1990s) presages that Thaw II might well be followed by Stagnation II.

The fact remains that Putin, who deems the collapse of the Soviet Union "the greatest geopolitical tragedy of the century," 74 has to deal with the Soviet legacy, i.e. with the remnants of a system in which the ideological pillars have crumbled. As it has been shown, this challenge identifies him to Khrushchev after the 20th Congress. In other places in other times, such a situation reminds one of another

${ }^{71}$ In that vein, see Richard Crossman, The God that Failed (New York: Harper \& Brothers, 1949). The volume gathered testimonies of famous ex-communists (among them Arthur Koestler and André Gide).

${ }^{72}$ The Putin Interviews, dir. Oliver Stone, June 2, 2017.

${ }^{73}$ From 14 until 17 September of the last year, during the joint strategic exercise "Zapad 2017" of Russian and Belarus armies, the Russian side has displayed 3,000 military personnel and about 280 vehicles, including up to 25 aircrafts and helicopters. For more details see "Details of Belarusian-Russian army exercise Zapad 2017 unveiled," Belarusian Telegraph Agency, March 20, 2017.

${ }^{74}$ Presidential Address to the Federal Assembly on 10 May 2006. 
ruler who lived far away in the past: the pharaoh Tutankhamun. ${ }^{75}$ The latter spent his entire reign undoing the radical religious innovations introduced by his father, Akhenaten, who had replaced Egyptian traditional polytheism by the quasimonotheistic cult of the Aten. Unexpectedly, his political doctrine sheds light on the stakes of Russian strategy today: "Tutankhamun attempted the impossible: to go back before a revolution in order to regain the past and to fix it in its splendor; but the big spiritual principles had been beaten to death. Akhenaten had destroyed those things that could never be replaced: beliefs." give a new life to those beliefs or to forge new ones will depend the legitimacy of Putin's regime. Both imply the strongest cultural artillery ever.

\section{Acknowledgments}

I would like to express my gratitude to Natalia Bubnova for her insightful comments and warm support. Needless to say, the views and opinions expressed in this article are my own.

\section{Bibliography}

Primary Sources

\section{Films:}

The Putin Interviews, dir. Oliver Stone, 2017.

The Death of Stalin, dir. Armando Ianucci, 2017.

Matilda, dir. Alexey Uchitel', 2017.

\section{Novels, newspapers and magazines:}

Ivan Shevtsov, Plant Louse (Moscow: Golos, 2000), 3.

Kochetov, V. Chego Zhe Ty Khochesh? (What Do You Want Then?), Letchworth-Herts: Prideaux Press, 1970 (first published in 1969 in the journal Oktîabr').

Yunost'

${ }^{75}$ Tutankhamun, pharaoh of the eightieth dynasty, ruled from 1332 until 1323 BC. Interestingly, the Soviet and the Egyptian rulers shared the same unenviable fate after their rule, as if great reformators were doomed to fall into oblivion once they completed their historical mission. Horemheb, Tutankhamun's successor, instigated a campaign of damnatio memoriae (condemnation of the memory, meaning that the person must be completely removed from public memory) against him and his family, hacking at their statues and erasing their images and cartouches. Like Horemheb to Tutankhamun, Brezhnev made Khrushchev disappear from the official video recordings, notably with Yuriū Gagarin. Besides, the Soviet people were not able to attend Khrushchev's funeral, the cemetery was by accident under construction that day. See Robert Hari, "La "damnatio memoriæ" amarnienne," in Mélanges Adolphe Gutbub, ed. by Adolphe Gutbub, Université Paul Valéry, 1984, 95-102.

${ }^{76}$ Geneviève R. Tabouis, Le Pharaon Tout Ank Amon. Sa Vie et son Temps (Paris: Payot, 1929), 301. 
Ogoniek

Kranaîa Zvezda

The New York Times

Secondary Sources

Adzhubey, A. (ed.). Litsom k litsu s Amerikoǔ (Face to Face with America). Moscow: Politizdat, 1960.

Aksîutin Y. "Khrushchevskă̌a Ottepel” i obshchestvennye nastroenŭa v SSSR v 1953-1964 gg. Moscow: Rosspen, 2010.

Bakhtin, M. Tvortchestvo François Rabelais i narodnaîa kul'tura srednevekov'îa $i$ Renesansa (The Art of François Rabelais and the Popular Culture in the Middle Ages and the Renaissance). Moscow: Khudozhestvennaîa Literatura, 1965.

Bertrand, G. Histoire du Carnaval de Venise. Paris: Pygmalion, 2013.

Bobkov, P. Struggling with “Agents of Influence?” How Putin Can Rebuild Russia. Moscow: Algoritm, 2014.

Brandenberger, D. National Bolshevism: Stalinist Mass Culture and the Formation of Modern Russian National Identity, 1931-1956. Cambridge, MA: Harvard University Press, 2002.

Brudny, Y. Reinventing Russia: Russian Nationalism and the Soviet State 19531991. Cambridge, MA: Harvard University Press, 1998.

Burlatski1̌, F. Nikita Khrushchev. Moscow: Ripol Classic, 2003.

Caute, D. The Dancer Defects: the Struggle for Cultural Supremacy during the Cold War. Oxford University Press, 2003.

Crossman, R. The God that Failed. New York: Harper \& Brothers, 1949.

Danow, D.K. The Spirit of Carnival: Magical Realism and the Grotesque. Lexington: University of Kentucky Press, 2004.

Dobrenko, E., "Uroki Oktiabrîa” (The Lessons of Oktîabr'), Voprosy Literatury, 2 (1995), 27-55.

Dymarski1̆, V. Vremena Khrushcheva. V liudiakh, faktakh i mifakh (In Khrushchev's Times. People, Facts and Myths). Moscow: AST, 2011.

Fritz, E., "The Soviet Union in the Third World: Purpose in Search of Power," The ANNALS, April 1969.

Fosler-Lussier, D. Music in America's Cold War Diplomacy. Berkeley: University of California Press, 2015.

Grogin, R.C. Natural Enemies. The United States and the Soviet Union in the Cold War, 1917-1991. Lanham : Lexington Books, 2001.

Grushin, B. Chetyre zhizni Rossii v zerkale oprosov obshchestvennogo mnenîa. Ocherki massovogo soznanîa rossiyan vremion Khrushcheva, Brezhneva, Gorbacheva i Eltsina v 4-h knigah. Zhizn' 1-îa. Epoha Khrushcheva (The Four Lives of Russia in the Mirror of Public Opinion Polls. Essays on the Russian Collective Consciousness under Khrushchev, Brezhnev, Gorbachev and Eltsin in four volumes. Life Number 1: Khrushchev's Time). Moscow: Progress-Traditsiîa, 2001. 
Gu Guan-Fu, "Soviet Aid to the Third World an Analysis of Its Strategy," Soviet Studies, 35-1 (1983), 71-89.

Hari, R. "La "damnatio memoriæ" amarnienne," in Mélanges Adolphe Gutbub d'Adolphe Gutbub, Université Paul Valéry, 1984, 95-102.

Hixson, W. Parting the Curtain: Propaganda, Culture, and the Cold War. New York: St Martin's Griffin, 1998.

Hooker, M.T. The Military Uses of Literature. Fiction and the Armed Forces in Soviet Literature. Westport: Greenwood Publishing Group, 1996.

Huntington, S.P. The Common Defense. New York: Columbia University Press, 1961.

Lifshitz, M. and Reinhardt, L. The Crisis of Ugliness. Moscow: Iskusstvo, 1968.

Mitrokhin, N. Russkaîa Partiîa: Dvizhenie Russkih Natsionalistov v SSSR, 19531985 gg. (The Russian Party: the Russian Nationalists'Movement). Moscow: Novoie Literaturnoie Obozrenie, 2003.

Mlechin, L. Khrushchev. Saint Petersburg: Amfora, 2015.

Parks, J.D. Culture, Conflict, and Coexistence: American-Soviet Cultural Relations, 1917-1958. Jefferson, NC: McFarland and Company, 1983.

Reid, S.E. "Who Will Beat Whom? Soviet Popular Reception of the American National Exhibition in Moscow, 1959," Kritika: Explorations in Russian and Eurasian History, 9 (4) (2008), 855-904.

Richmond, Y. Cultural Exchange and the Cold War: Raising the Iron Curtain. University Park, PA: Penn State University Press, 2004.

Saunders, F.S. Who Paid the Piper? The CIA and the Cultural Cold War. London: Granta Books, 2000.

Strokov, P. Vsevolod Kochetov. Stranitsy zhizni, stranitsz tvorchestva (Vsevolod Kochetov. Pages of his Life and Work). Moscow: Sovremennik, 1985.

Tabouis, G.R. Le Pharaon Tout Ank Amon. Sa Vie et son Temps. Paris: Payot, 1929.

Taubman, W. Khrushchev: The Man and His Era. New York: Norton and Company, 2004.

Thomas, H. Armed Truce. The Beginnings of the Cold War. 1945-1946. London: Sceptre, 1988.

Vail, P. and Genis, A. 60-ie: Mir Sovetskogo Cheloveka (The 1960s: the World the Soviet Man). Moscow: Corpus, 2013.

Von Eschen, P.M. Satchmo Blows Up the World: Jazz Ambassadors Play the Cold War. Cambridge, MA: Harvard University Press, 2004.

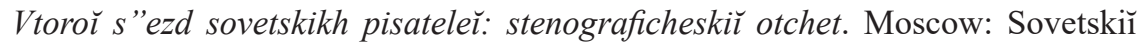
pisatel', 1956.

Zubok, V. A Failed Empire: the Soviet Union in the Cold War from Stalin to Gorbachev. Chapell Hill: the University of North Carolina Press, 2007.

Zhit'v mire $i$ druzhbe (Living in Peace and Friendship), translated into english Khrushchev in America. Moscow: Gospolitizdat, 1959. 